\title{
Communication Failures in Everyday Conversations: a Case Study Based on the "Retrospective Commenting Method"
}

\author{
Arto Mustajoki \\ ${ }^{1}$ HSE University, Moscow \\ Staraya Basmannaya, 21/4 \\ 105066, Moscow, Russia \\ ${ }^{2}$ Helsinki University, Finland \\ arto.mustajoki@helsinki.fi
}

\author{
Natalia Cherkunova \\ HSE University, \\ St. Petersburg, 123A Kan. \\ Griboedova Emb. 190068, \\ St. Petersburg, Russia \\ nbcherkunova@edu.hse.ru
}

\author{
Tatiana Sherstinova \\ HSE University, \\ St. Petersburg, 123A Kan. \\ Griboedova Emb. 190068, \\ St. Petersburg, Russia \\ tsherstinova@hse.ru
}

\begin{abstract}
The paper deals with communication failures in everyday spoken discourse. The spontaneous character of oral speech is its basic property and becomes a prerequisite for the appearance of such a phenomenon as communicative failures. By communicative failures, we mean speech situations when the recipient of a speech message does not understand it correctly, i.e., in the way the speaker intended. The purpose of this pilot study is 1) to assess the total number of communication failures that occur with a person during a single day and 2) to determine the dependence of communication failure frequency on the communication settings and conditions. The main result of the study is a qualitative and quantitative assessment of communication failures during a subjects's day. The research is based on a special experiment based on 24-hour monitoring of the subject's speech and his subsequent retrospective commentary on all recorded data. Such an approach allows one to reduce the subjectivity inherent in much linguistic work. The research continues a series of studies devoted to the effectiveness of spoken communication and is important not only for understanding the fundamental processes of speech perception but is also crucial for the development of artificial intelligence systems involving human-computer speech dialogue systems and for speech technologies of the next generation.
\end{abstract}

Keywords: everyday speech communication; spoken Russian; dialogue structure; speech corpus; oral discourse; miscommunication

DOI: $10.28995 / 2075-7182-2021-20-514-523$

\section{Коммуникативные Неудачи в Повседневном Речевом Общении: Пилотное Исследование с Использованием Метода Ретроспективного Комментирования}

\author{
Арто Мустайоки \\ ${ }^{1}$ НИУ ВШЭ, Москва \\ Старая Басманная, 21/4, \\ 105066, Москва, Россия \\ ${ }^{2}$ Хельсинский университет, \\ Финляндия \\ arto.mustajoki@helsinki.fi nbcherkunova@edu.
}

\author{
Татьяна Шерстинова \\ НИУ ВШЭ, \\ Санкт-Петербург \\ Наб. Канала Грибоедова \\ 123A, 190068, \\ Санкт-Петербург, Россия \\ tsherstinova@hse.ru
}

\begin{abstract}
Аннотация
В статье рассматриваются коммуникативные неудачи в повседневном устном дискурсе. Спонтанность устной речи является ее базовым свойством и является предпосылкой возникновения такого явления, как коммуникативные неудачи. Под коммуникативными неудачами мы понимаем речевые ситуации, когда адресат речевого сообщения понимает его неправильно, т. е. не так, как задумал говорящий. Целями данного пилотного исследования является: 1) оценка общего количества коммуникативных неудач, которые происходят с человеком в течение одного дня и 2) определение зависимости частоты коммуникативных неудач от условий коммуникации. Главный результат исследования - количественная оценка коммуникативных неудач
\end{abstract}


информанта в течение дня и их качественная интерпретация. Предлагаемое исследование основано на специальном эксперименте, основанном на круглосуточном мониторинге речи испытуемого и его последующем ретроспективном комментарии ко всем записанным данным. Такой подход позволяет уйти от субъективизма, присущего многим лингвистическим исследованиям. Эта работа продолжает серию исследований, посвященных эффективности речевого общения, полученные результаты важны не только для понимания фундаментальных процессов восприятия речи, но также имеют решающее значение для разработки систем искусственного интеллекта, включающих системы речевого диалога человек-компьютер, а также для речевых технологий следующего поколения.

Ключевые слова: повседневная речевая коммуникация; русская разговорная речь; структура диалога; речевой корпус; устный дискурс; коммуникативные неудачи

\section{Introduction}

The research continues a series of studies devoted to the effectiveness of spoken communication. The spontaneous character of oral speech is its basic property and becomes a prerequisite for the appearance of such a phenomenon as communicative failures. By communicative failures, we mean speech situations when the recipient of a speech message does not understand it correctly, i.e., in the way the speaker intended.

The causes and risks of miscommunication have been widely discussed in the research literature (see e.g. $[1 ; 2 ; 3 ; 4 ; 5 ; 6 ; 7 ; 8 ; 9 ; 10])$. However, there is very little evidence about the frequency of communication failures.

If people are asked whether they have had any communication failures during a day, they usually say one or two or just none. One example of this is the experiments aimed at counting communication failures during a single day by a group of philology students at the National Research University Higher School of Economics, St. Petersburg. The students were asked to keep a "miscommunication diary" and register all communication failures they have. The number of communication failures turned out to be from 0 to 2 on average. A comparable experiment was conducted among students at Helsinki University and the results were similar. This means that we usually do not identify and register communication failures even in a situation where we should collect them. In everyday life, people remember only the most drastic communication failures which have had serious or amusing consequences.

There are some quantitative studies on very specific communication situations, e. g. in conversation concerning railway and air traffic control $[11 ; 12]$ and health care contexts [13]. However, there is very little data on the frequency of communication failures in everyday settings, Ermakova's and Zemskaya's study [14] being an exception. On the basis of a large amount of authentic material, they arrived at the conclusion that communication failures are more frequent in everyday speech with family members and good friends than in conversation with strangers. The results sound paradoxical but there are good reasons for this $[15 ; 16]$.

Ermakova's and Zemkaya's study is rich source of materials and has been carried out very thoroughly but is suffers from a methodological gap which is a major problem in research on miscommunication. If a researcher examines interaction between people as an observer or uses video or audio recording, $\mathrm{s} / \mathrm{he}$ is unable to identify all the instances of misunderstandings. As shown e.g. in $[17 ; 18 ; 19 ; 20]$, misunderstandings are often latent or covert. Recipients tend to apply the "let it pass" tactic [21]. There are various reasons for not asking for clarification in the case of misunderstanding: (1) the topic is not interesting for the recipient; (2) s/he thinks that s/he has already understood enough; (3) s/he believes that $\mathrm{s} / \mathrm{he}$ will later understand what was said; (4) s/he does not want to interrupt the course of interaction; (5) $\mathrm{s} /$ he does not want to show her/his ignorance.

The purpose of the study presented in this paper was 1) to assess the total number of communication failures that occur with a person during a single day and 2) to determine the dependence of communication failure frequency on the communication settings and conditions.

\section{The "Retrospective Commenting Method" and Methodology}

In [22] a new methodological tool was presented to gain a deeper insight into the problems of communication. The "Retrospective Commenting Method" (RCM) aims to tackle the weakness of other methods by working afterwards on a recorded material with the informant. The new method is quite laborious but enables one to get more precise information on what really took place in a conversation. 
The main stages of the methods are the following (see in detail [22]):

1) The first stage consists of recording all the communication the informant has had during one day. This takes place within the "One Day of Speech" project which is currently being conducted at Saint Petersburg University $[23 ; 24 ; 25 ; 26]$. This material is valuable as such, and much research has been done on the basis of "one day communication packages" of more than one hundred informants. Before the recording, the subject was asked to note the situations of miscommunication during the day of recording [22].

2) What is new in the RCM is the second stage, namely the way the recorded material is analysed. It takes place with the active participation of the informant. S/he (she in the pilot study) goes through the whole recorded material with the researcher, commenting on what really occurred in the communication settings she had during the day. Before listening to audio recording together with the researcher, the participant was told that she should note and comment the followings aspects of her recorded communication:

- The main task was to distinguish and describe miscommunication situations and any other types of communicative failures (e.g., when something was understood in a different way from what was intended by the speaker, when the participant did not understand something from the speech of her interlocutor but chose to pretend that everything was fine, or when the informant believed that she was misunderstood, etc.).

- Then, she should explain to the researcher any communication situations that a stranger could not understand correctly. It included description (clarification) of the communication context or some phrase/word meaning: (Here, I am talking about ...), attribution of emotions (e.g., At this moment I am very annoyed, but I try not to show it.), explanation of her dialogue tactic (e.g., I am speaking this way because...), revealing hidden humour, irony, or language play (Here, I am being ironic.), etc.

The researcher was listening to the recording with the participant, they discussed the recording together and this discussion was also recorded. The examination of one day's material took three days in the pilot study [22].

The total amount of audio material received was 22.5 hours: 8.5 hours of source material and 14 hours of recording of the commenting process.

Experiment participant: woman, 40 years old. Profession: actress, art critic, and university professor. During the day, the informant interacts with:

- her mother;

- her daughter;

- her husband;

- a doctor at an outpatient clinic;

- her colleagues;

- her students;

- and occasional strangers.

\section{Results: Daily Communication Failures in Numbers}

The experiment shows that the retrospective commenting method enables one to go much deeper into decisions made by interlocutors than a normal examination of recorded material by the researcher her/himself alone. However, the job of informant is not always easy. What is most difficult to identify are those communicative failures in which there is no obvious conflict of interests and opinions. Another unclear situation occurs when the interlocutor stops communication (for example, leaves the room) or simply abruptly changes the topic of conversation. For the informant, being unable to read the interlocutor's thoughts in detail, it is difficult to identify the presence of a communication failure.

A further observation on the process of analysis of the material by the informant was that from the 19 communication failures, she identified only 13 instantly. The remaining 6 required the involvement of the assisting researcher.

The most surprising and important result was the total number of communication failures that occurred during the day, being as many as 19 . Naturally, it is also interesting to see which categories they belong to. In analyzing them, we apply the following criteria of classification: 
- place of communication and recipient;

- reasons for communication failures;

- resolved or unresolved communication failure.

Table 1 shows the distribution of communication failures, depending on the place of communication and recipient. According to the data, $10(53 \%)$ of the total number are communication failures that occurred in the informant's home during communication with relatives. There were 5 failures at work and 4 in public places.

The main conclusion which can be made on the basis of this table is the great variety of reasons for communication failures, four being the highest number. There are slight differences in the numbers concerning domestic and external conditions, but one cannot see on that basis any reliable differences. Each type will be described in more detail below.

\begin{tabular}{|c|c|c|}
\hline Place of communication & Participant & Total number \\
\hline At home $(53 \%)$ & $\begin{array}{c}\text { Mother }-6 \\
\text { Daughter }-4\end{array}$ & 10 \\
\hline At work $(26 \%)$ & $\begin{array}{c}\text { Students }-3 \\
\text { Colleagues }-2\end{array}$ & 5 \\
\hline $\begin{array}{c}\text { Other places (medical center, } \\
\text { university) }(21 \%)\end{array}$ & $\begin{array}{c}\text { Doctor }-1 \\
\text { Strangers }-3\end{array}$ & 4 \\
\hline
\end{tabular}

Table 1: Distribution of communication failures depending on the place of communication and the interlocutors (recipients)

Table 2 presents the reasons for communication failures that occurred during the day of recordings divided into two groups: domestic and external.

\begin{tabular}{|c|c|c|c|}
\hline Reasons & Domestic & External & $\begin{array}{c}\text { Total } \\
\text { number }\end{array}$ \\
\hline Lack of interest in communication & 2 & 2 & 4 \\
Emotional effect & 1 & 2 & 3 \\
Insufficient volume (noise) & 1 & 2 & 3 \\
Distortion of information & 1 & 1 & 2 \\
Opinion imposition & 2 & 0 & 2 \\
Wrong interpretation & 1 & 1 & 2 \\
Incomplete information & 1 & 1 & 2 \\
Abrupt change of topic & 0 & 1 & 1 \\
Joke & 0 & 1 & 1 \\
\hline
\end{tabular}

Table 2: The main reasons for communication failures

Finally, Table 3 illustrates the ratio of resolved and unresolved communication failures.

\begin{tabular}{|c|c|}
\hline Type & Percent \\
\hline Resolved & $61 \%$ \\
Unresolved & $33 \%$ \\
Ambiguous & $6 \%$ \\
\hline
\end{tabular}

Table 3: The ratio of resolved and unresolved communication failures

Unresolved communication failures are understood as those episodes of communication in which no attempt is made to clarify the situation (e. g., the interlocutor leaves the room or changes the topic). We may see that in our data one third of all communication failures remained unresolved. 


\section{Examples of Communication Failures and Their Settings}

Let us have a look at some concrete examples of communication failures. As was shown, the most frequent reason for communication failures is a lack of interest in communication.

\subsection{Lack of interest in communication}

Case 1

- Participants in the communication: A — the informant; B — informant's mother.

- Setting: at home.

- Communication time: morning.

- Situational context: a dialogue about one of the informant's acquaintances.

- Transcript:

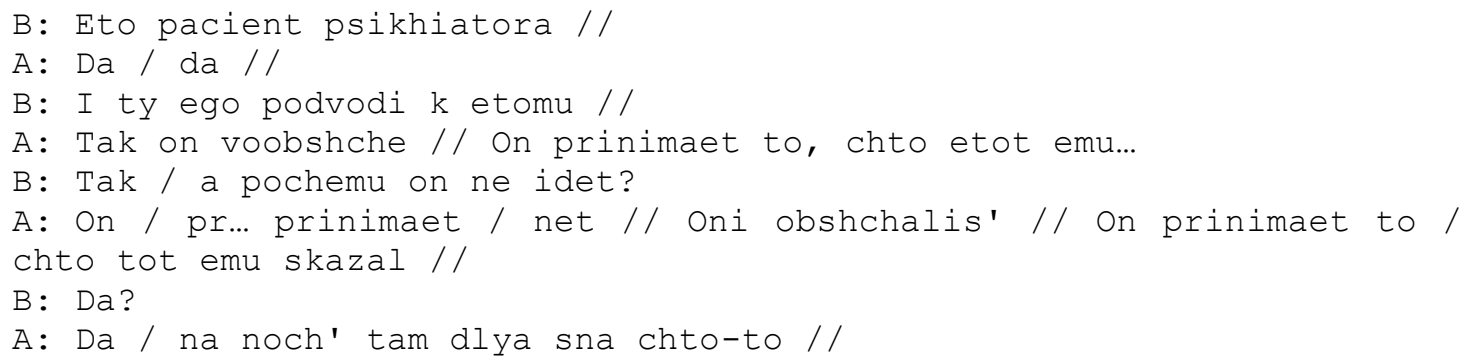

- Translation:

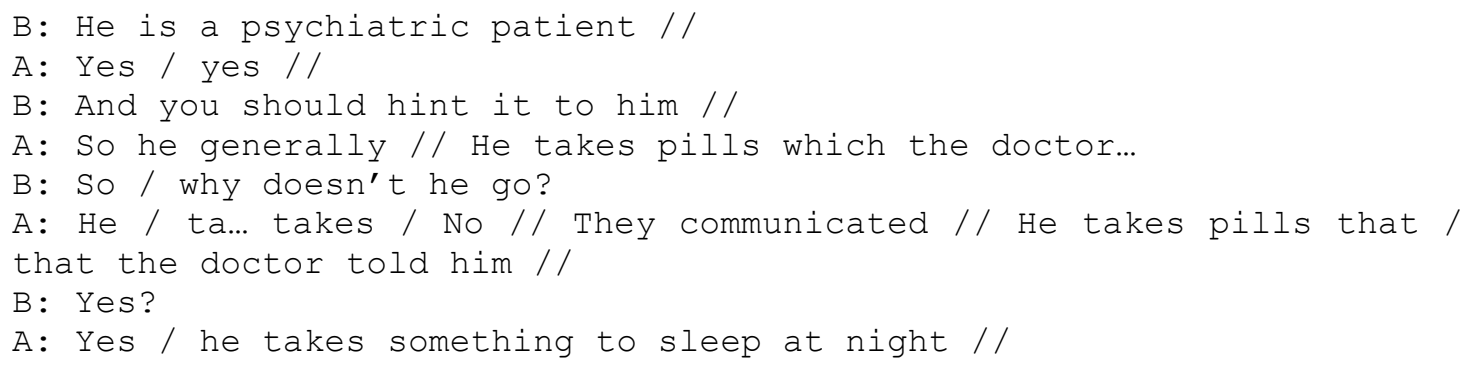

- Communication failure: resolved.

- Comment: Although a person is busy with something, family members often continue to communicate with her/him. Here the informant is looking for documents to visit the clinic and her mother tries to involve her in communication. As a result, the answers become short and rather meaningless. The informant apparently does not pay due attention to the dialogue. However, when the informant clearly explains his thought, the communication failure becomes resolved.

Case 2

- Participants in the communication: A - informant; B - her colleague.

- Setting: in the university.

- Communication time: afternoon.

- Situational context: the informant tries to relax in the teaching room. Her colleague enters the room and begins to tell a story about his relatives.

- Transcript:

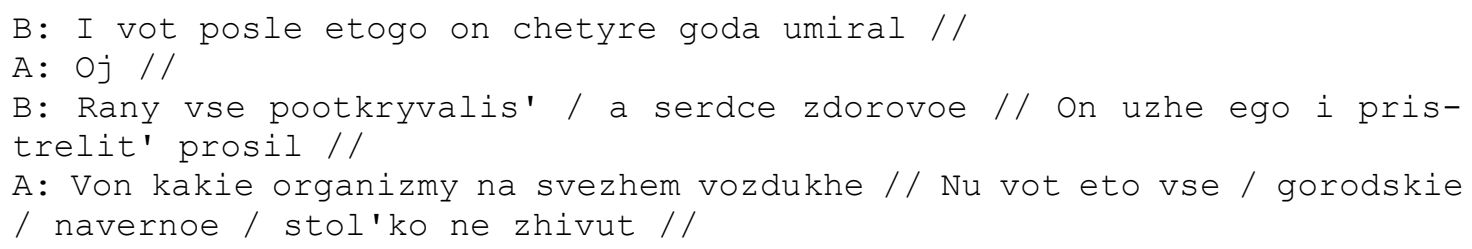


B: Vot etot vot ded / kotoromu devyanosto shest' s polovinoj let / dedu moemu / v devyanosto let doma rubil //

- Translation:

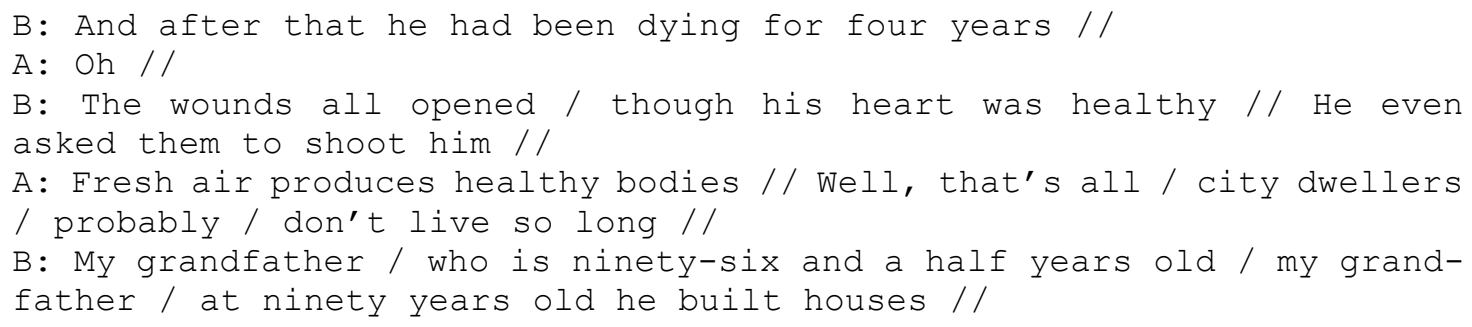

- Communication failure: unresolved.

- Comment: In this case, the goals of the participants in the dialogue are different. The informant's interlocutor wants to get a story off his chest (so-called unburden speech, cf. [6, 27]). It is important for him to be heard, but he is not interested in a real dialogue and simply ignores the informant's reaction. This miscommunication is unsolved, because the informant ends the conversation, referring to the fact that it is time for her to go to her students for an exam.

\subsection{Opinion imposition}

Case 3

- Participants in the communication: A - informant; B - the informant's daughter.

- Setting: at home.

- Communication time: morning.

- Situational context: the informant's daughter wakes up. The informant is going to play a goose game they have invented with her daughter.

- Transcript:

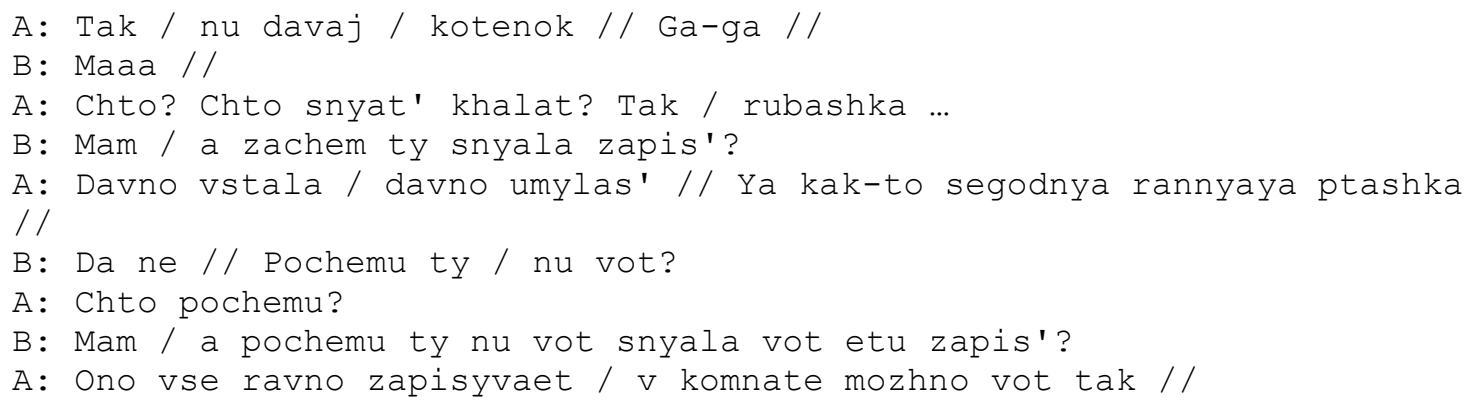

- Translation:

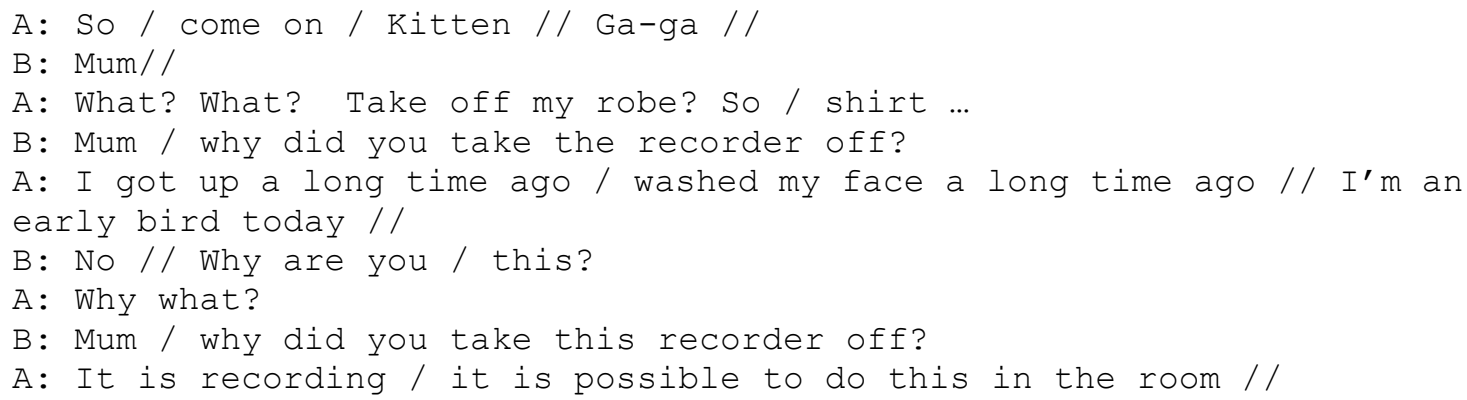

- Communication failure: resolved

- Comment: Communication with children deserves special attention and an appropriate recipient design. Parents in most cases are not fully involved in children's games but respond with routine phrases. In this case, the informant tries to impose her opinion on the child (to predict what the 
daughter wants from her). The situation is resolved when the child for the third time clearly formulates his question.

\subsection{Emotional effect}

Case 4

- Participants of communication: A - informant; B - a stranger.

- Setting: in the university.

- Communication time: afternoon.

- Situational context: a security guard at the university asks the informant to escort a man to the office he is looking for.

- Transcript:

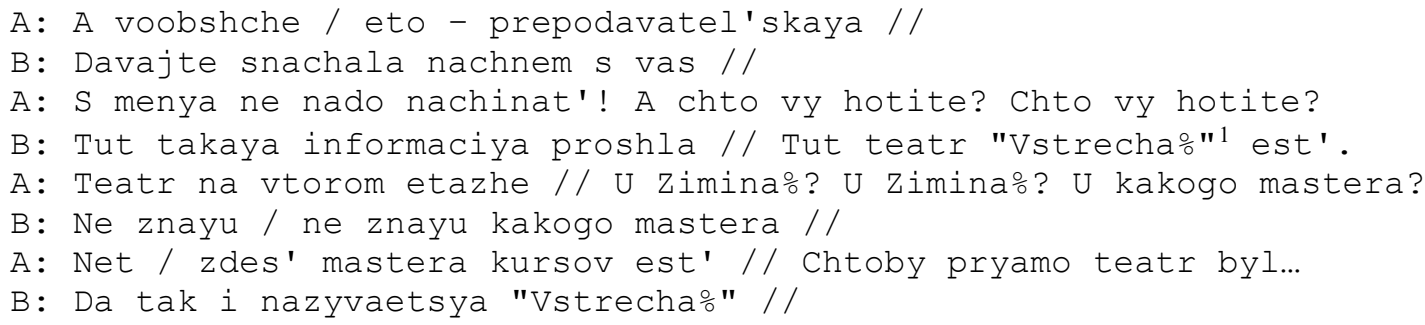

- Translation:

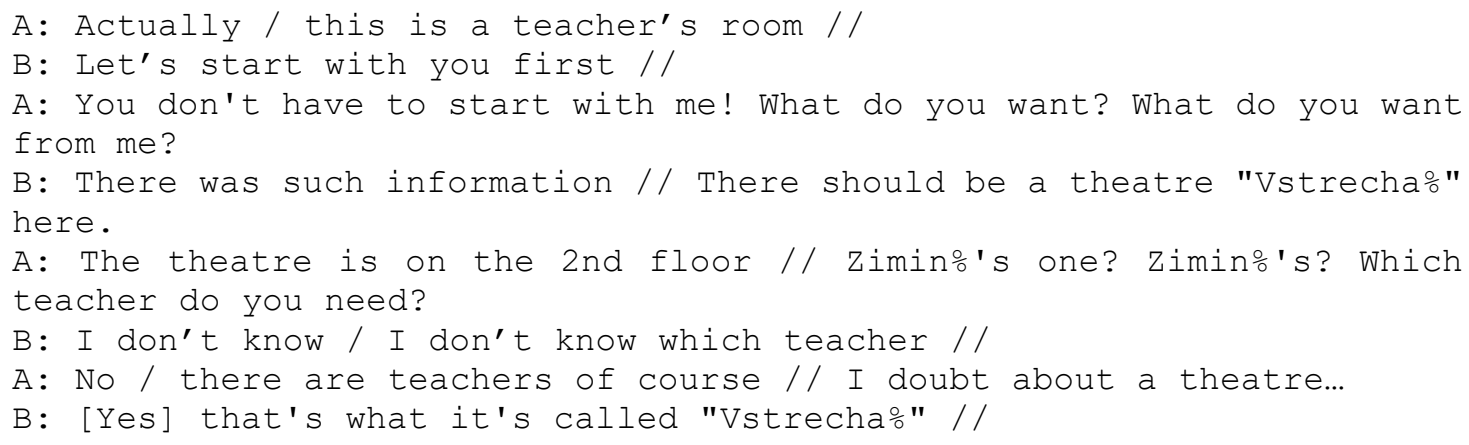

- Communication failure: not resolved.

- Comment: When talking with the stranger, the informant feels disturbed by his phrase "Let's start with you first", which she perceives as his misplaced attempt to flirt. For this reason, the informant becomes uncomfortable and reacts emotionally "You don't have to start with me! What do you want? What do you want from me?", as if suspecting her interlocutor might be insane or an agent. Such a reaction means that the stranger explains his position and the conversation proceeds. However, the intent of his disturbing remark, which causes miscommunication, remains unknown.

\section{Conclusion}

The study was based on a special experiment on 24-hour monitoring of the subject's speech and his/her subsequent retrospective commentary on all recorded data. Such an approach, where a participant of interaction him/herself comments and describes the details of spoken interaction is unique in linguistic corpus studies and allows one to make research less subjective. The method used enables us to get not only qualitative but also some quantitative data on communication failures. To our knowledge, this is the first attempt to get a real picture of the frequency of communication failures in settings of everyday conversation. In this pilot study, we examined only one day's interaction of a single person. Therefore,

\footnotetext{
$1 \%$ - all proper names are anonymized.
} 
one cannot make far-going conclusions on this basis. However, we got important hints about the frequency and forms of miscommunication in everyday communicative settings.

The main result of the study is a rather large number of communication failures during the subject's day - 19. If every person in the world meets on average at least 10 communication failures a day, it means that billions situations of miscommunication take place every single day. One can only image the damage caused by them. An unrealistic goal should be to try to free the world from failures in communication totally, but more research could give us tools to reduce their number. Even a small reduction of cases of miscommunication should make the world a better place to life.

A further important outcome of the study is a positive experience of using the retrospective commenting method. The method has, naturally, its own limitations but in comparison to traditional methods, it gives a much more reliable picture of the reality of a face-to-face everyday interaction. In the process of analyzing communication, difficulties arose with settings in which the situation had no outcome. In other words, communication is interrupted for some reason (for example, one of the communication participants leaves the room) or a completely new topic of dialogue is introduced into the communication. These situations need more attention during the commenting process. All in all, the method could provide a deeper insight into other big themes of interactional linguistics, e.g., a realization of the principles of politeness [28] and cooperation [29]. A further topic could be turn-taking, a central question in conversational analysis [30].

As to the concrete forms of communication failures, only very preliminary observations can be made. First, they are very diverse. Altogether eight different reasons were identified. This tells of the main characteristic of everyday interaction: it changes all the time and a setting is never repeated in the same form as it first took place.

A second observation confirms the claim that home is a rather "dangerous place" for communication (cf. $[27 ; 14 ; 16])$. This is a rather controversial discovery, because interaction with people you know well should be much easier than meeting with people without such a common ground. However, as shown in [31], domestic circumstances include some features which are favorable to communication failures. People are relaxed when spending their leisure time and do not always want to concentrate on interaction. They feel overconfident and take risks by relying on common ground. This results in the use of cryptic speech by the speaker and non-listening and overguessing by the recipient.

A third general remark concerns the reasons for communication failures. The study shows that they are very seldom purely linguistic, e. g. ambiguous constructions or vague meanings of words. More often, they come from circumstances and/or poor concentration on interaction by the communicants. Therefore, the main reason for communication failures, regardless of the communication conditions, seems to be insufficient involvement in the communication process. This violates the basic principle of successful interaction - cooperation.

Being the first pilot study of its kind, the results provide important building blocks for better understanding of the fundamental processes of spoken communication. In addition to that, the results should also be considered in the development of artificial intelligence systems involving human-computer speech dialogue systems and for speech technologies of the next generation.

Evidently, miscommunication in spoken interaction needs much more research. An important issue which remains totally unclear, is the borderline between sufficient understanding and non-sufficient understanding (cf. [32; 33]). The results obtained are important for a deeper understanding of the fundamental processes of spoken communication. They should be also taken into account when artificial intelligence systems involving human-computer interaction based on speech technologies are developed.

\section{Acknowledgements}

The experiment of longitudinal recording and its Retrospective Commenting Method which gave speech data for the given research was supported by the University of Helsinki. The methodology of longitudinal recording was approved during the creation of the ORD speech corpus, which is being created in St. Petersburg State University and was supported by several grants: the Russian Foundation for Humanities projects \# 07-04-94515e/Ya (Speech Corpus of Russian Everyday Communication "One Speaker's Day"), \#12-04-12017 (Information System of Communication Scenarios of Russian Spontaneous Speech). Significant extension of the corpus was achieved in the framework of the project 
"Everyday Russian Language in Different Social Groups" supported by the Russian Scientific Foundation, project \# 14-18-02070.

\section{References}

[1] Falkner W. Verstehen, Missverstehen und Missverständnisse: Untersuchungen an einem Korpus englischer und deutscher Beispiele. - Tübingen: Niemayer, 1997.

[2] Bazzanella C. and Damiano R. The interactional handling of misunderstanding in everyday conversations // Journal of Pragmatics. — 1999. — T. 31. - Vol. 6. — pp. 817-836.

[3] Dascal M. Introduction: Some questions about misunderstanding // Journal of Pragmatics. - 1999. - T. 6. - Vol. 31. - pp. 753-762.

[4] Tzanne A. Talking at Cross-Purposes: The Dynamics of Miscommunication. - Amsterdam/Philadelphia: John Benjamins. — 2000.

[5] House J., Kasper G., Ross S. Misunderstanding talk // Misunderstanding in social life. — Routledge, 2014. - pp. 9-29.

[6] Mustajoki A. A speaker-oriented multidimensional approach to risks and causes of miscommunication // Language and dialogue. — 2012. - T. 2. - Vol. 2. - pp. 216-243.

[7] Verdonik D. Between understanding and misunderstanding //Journal of Pragmatics. — 2010. — T. 42. - Vol. 5. - pp. 1364-1379.

[8] Roberts G., Langstein B., Galantucci B. (In) sensitivity to incoherence in human communication // Language \& Communication. - 2016. - T. 47. - pp. 15-22.

[9] Bazzanella C. The complex process of mis/understanding spatial deixis in face-to-face interaction// Pragmática Sociocultural / Sociocultural Pragmatics - 2019. - T. 1. - Vol.7. - pp. 1-18.

[10] Honghui Z., Dongchun C. Understanding misunderstandings from socio-cognitive approach to pragmatics // International Journal of Language and Linguistics. —2019. — T. 5. —Vol. 7. — pp. 194-201.

[11] Gibson W. H. et al. A taxonomy of human communication errors and application to railway track maintenance // Cognition, Technology \& Work. — 2006. - T. 8. - Vol. 1. - pp. 57-66.

[12] Gibson T., Megaw T., Donohoe L. Failures in pilot-controller communications and their implications for datalink // Engineering Psychology and Cognitive Ergonomics. - Routledge, 2016 - Vol. 5. - pp. 325334.

[13] Docherty N.M., McCleery A., Divilbiss M., Schumann E.B., Moe A., Shakeel M. K. Effects of social cognitive impairment on speech disorder in schizophrenia // Schizophrenia Bulletin. — 2013. - T. 3. — Vol. 39. - pp. 608-616.

[14] Ermakova O.V., Zemskaya E.A. (1993), K postroyeniyu tipologii kommunikativnykh neudach [Towards the construction of a typology of communicative failures] // Russkiy yazyk v yego funktsionirovanii. Kommunikativno-pragmaticheskiy aspect [Russian language in its functioning. Communicative and pragmatic aspect], Moskow: Nauka, pp. 90-157.

[15] Mustajoki A. Why is miscommunication more common in everyday life than in lingua franca conversation // Current issues in intercultural pragmatics. - 2017. - pp. 55-74.

[16] Mustajoki A. (2011), Pochemu obshchenie na lingua franca udaetsia tak khorosho [Why interaction in a lingua franca is so successful] // Iazyki sosedej: mosty ili bar'ery? Problemy dvuiazychnoi kommunikatsii [The languages of the neighbors: bridges or barriers? Problems of bilingual communication], St Petersburg: Institut ligvisticheskikh issledovanii RAN, Evropeiskii universitet, pp. 10-31.

[17] Linell P. et al. Troubles with mutualities: Towards a dialogical theory of misunderstanding and miscommunication // Mutualities in dialogue. - 1995. - pp. 176-213.

[18] Hinnenkamp V. Constructing misunderstanding as a cultural event // Culture in Communication: Analyses of Intercultural Situations. - Amsterdam/Philadelphia: John Benjamins, 2001. — pp. 211-243,

[19] Hinnenkamp V. Misunderstandings: Interactional structure and strategic resources // Misunderstandings in Social Life: Discourse Approaches to Problematic Talk. — London etc.: Longman, 2003 - - pp. 57-81.

[20] Pietikäinen K. S. Misunderstandings and ensuring understanding in private ELF talk // Applied Linguistics - 2016. - pp. 1-26.

[21] Firth A. The lingua franca factor // Intercultural Pragmatics. — 2016. - T.2. — Vol.6. - pp. 147-170.

[22] Mustajoki A., Sherstinova T. The "Retrospective commenting" method for longitudinal recordings of everyday speech // International Conference on Speech and Computer. — Springer, Cham, 2017. - pp. 710-718.

[23] Asinovsky A. et al. The ORD speech corpus of Russian everyday communication "One Speaker's Day": creation principles and annotation // International Conference on Text, Speech and Dialogue. - Springer, Berlin, Heidelberg, 2009. - pp. 250-257.

[24] Sherstinova T. The structure of the ORD speech corpus of Russian everyday communication // International Conference on Text, Speech and Dialogue. — Springer, Berlin, Heidelberg, 2009. — pp. 258-265. 
[25] Bogdanova-Beglarian N., Sherstinova T., Blinova O., Ermolova O., Baeva E., Martynenko G., Ryko A. Sociolinguistic extension of the ORD corpus of Russian everyday speech //International Conference on Speech and Computer. - Springer, Cham, 2016. - pp. 659-666.

[26] T. Sherstinova. Studying Linguistic Variation and Communicative Diversity on the Basis of the "One Day of Speech" Corpus // Urban Voices: Studies in Sociolinguistics, Grammar and Pragmatics of Spoken Russian. — Peter Lang Int. Ac. Publ, 2019. — pp. 15-36.

[27] Mustajoki A., Sherstinova T., Tuomarla U. Types and functions of pseudo-dialogues // From Pragmatics to Dialogue. - 2017. - T. 31. - pp. 189-216.

[28] Leech G. N. Principles of Pragmatics London: Longman Group Ltd. - 1983.

[29] Grice H. P. Logic and conversation // Speech acts. - Brill, 1975. - C. 41-58.

[30] Sacks H., Schegloff E.A., Jefferson G.A. A simplest systematics for the organization of turn-taking in conversation // Language. - 1974 - Vol. 50. — pp. 696-735.

[31] Mustajoki A., Bajkulova A. The risks of misunderstandings in family discourse: Home as a special space of interaction // Language and Dialogue. - 2020. - T. 10. - Vol. 3. - pp. 340-368.

[32] Gander A. J. Understanding in real-time communication: Micro-feedback and meaning repair in face-to-face and video-mediated intercultural interactions // URL: http://hdl. handle. net/2077/56223. — Gothenburg: BrandFactory, 2018.

[33] Gander A. J., Gander P. Micro-Feedback as Cues to Understanding in Communication //CLASP Papers in Computational Linguistics. - pp. 1-11. 